\title{
Carcinoid heart disease
}

\author{
Stephen A. Gellera , Fernando P. F. Campos ${ }^{b}$
}

Geller SA, Campos FPF. Carcinoid heart disease. Autopsy Case Rep [Internet]. 2013;3(1): 67-8. http://dx.doi.org/ 10.4322/acr.2013.010
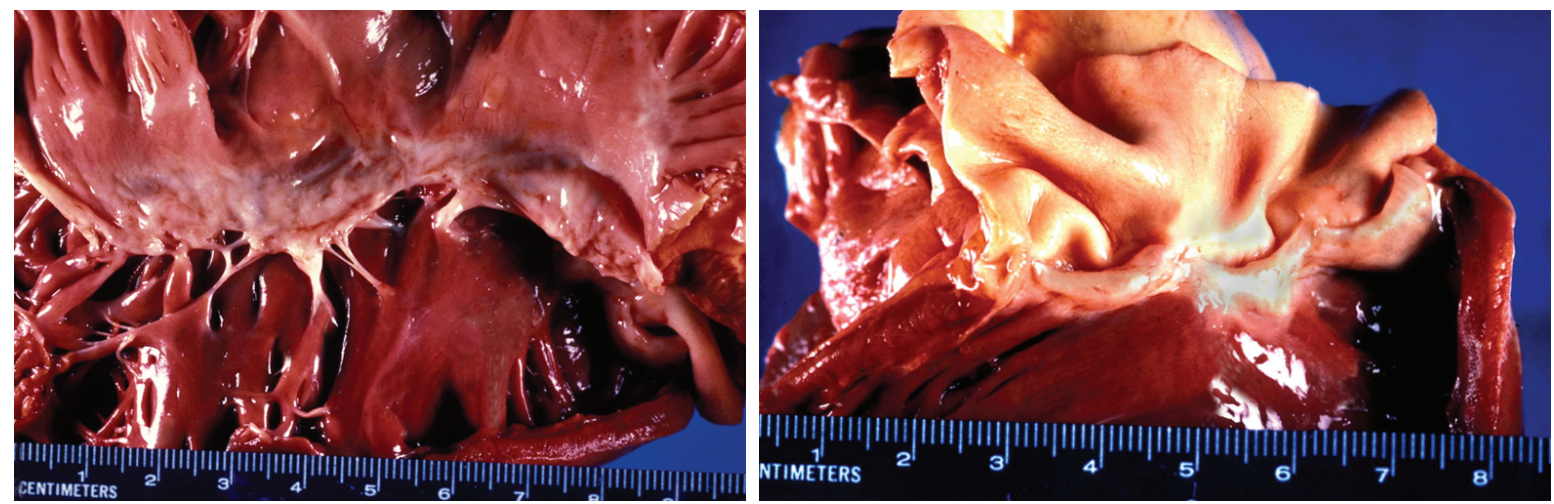

Pictures provided by Dr Stephen A Geller - personal archive.

The images are of the tricuspid valve and the pulmonic valve from the autopsy of a patient with mid-gut neuroendocrine carcinoma, carcinoid pattern, extensively metastatic to the liver. The patient had typical "carcinoid syndrome," including clinical evidence of tricuspid and pulmonic stenosis and insufficiency. The tricuspid valve (left) shows slight retraction and distortion by the overlying endothelial deposition of plaque composed of acid mucopolysaccharide-rich matrix with varying amounts of smooth muscle cells and collagen fibers. The plaque material causes partial coalescence of chordae tendinae with effacement of the usual delicate strands. The pulmonic valve (right) shows more marked distortion with shrinkage and obliteration of cusps and coalescence at the commissures. Beneath the plaque the valves are intact.

Neuroendocrine neoplasms (NEN) derive from scattered cells throughout the body, classically identifiable by their histochemical reactivity for chromium and silver salts, named as enterochromaffin cells, argentaffin cells, clear cells, enteroendocrine cells or Kultschitsky cells. Currently, immunohistochemical reactions are the preferred and more sensitive means of confirming the identity of these tumors, with antibodies directed against a variety of cell products, including chromogranin A, synaptophysin, and various other secretory products. The biological behavior of this group of tumor varies from slow-growing to highly aggressive. These tumors may arise in almost any organ of the abdomen, thorax, neck, skin, and gonads, but they are most commonly observed in the gastroenteropancreatic system and the lung. The term "karzinoide" (carcinoid) was first used by Oberndorfer in 1907 to describe invasive tumors with relatively bland histologic features. These tumors synthesize, store and release as many as 40 products, including serotonin, histamine, tachykinins, kallikrein and prostaglandins. The liver inactivates these bioactive products secreted into the portal circulation, explaining why the carcinoid syndrome is typically observed when there are liver metastases. Exceptions to this occur when biologically active neuroendocrine tumors arise in organs not drained by the portal vein, such as lung and ovary, so the products are secreted directly into pulmonic veins to reach the general circulation and can lead to left-sided heart disease. Both right and left sided valves are affect in the rare instances of

\footnotetext{
a Department of Pathology and Laboratory Medicine - David Geffen School of Medicine, UCLA, Los Angeles/CA - USA.

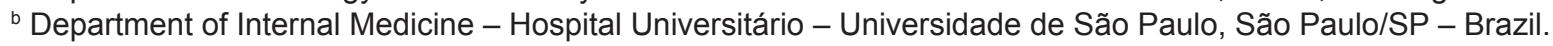

Copyright $\odot 2013$ Autopsy and Case Reports - This is an Open Access article distributed of terms of the Creative Commons Attribution NonCommercial License (http://creativecommons.org/licenses/by/3.0/) which permits unrestricted non-commercial use, distribution, and reproduction in any médium provided article is properly cited. 
shunting, as with a patent foramen ovale. Carcinoid syndrome is a symptom complex manifested by episodic flushing, secretory diarrhea, bronchospasm and hypotension. This syndrome occurs in $20 \%$ to $30 \%$ of patients at the time of diagnosis.

Carcinoid heart disease (CHD) occurs in as many as $60 \%$ of patients with the carcinoid syndrome. Recognizable plaque-like endocardial fibrous tissue deposits characterize this cardiopathy. The extension and pattern of plaque deposits is highly variable from focal to diffuse. Tricuspid valve involvement predominantly results in regurgitation. In contrast, pulmonic valve disease is often both stenotic and regurgitant. The combination of pulmonic stenosis and tricuspid regurgitation results in unfavorable hemodynamic consequences, because the former increases the degree of tricuspid insufficiency.

The precise pathogenesis of valve injury in CHD is not completely understood. Studies using cell cultures showed a stimulatory action of serotonin on subendothelial cell proliferation. In humans, the role of serotonin in the development of valvular pathology is based on indirect evidence, although it has been shown that the plasma levels of serotonin and 5-hydroxy-indolacetic acid (5-HIAA) correlate with the severity of right heart lesions. Other factors, such as genetic predisposition, could also play an important role, and apart from serotonin and 5-HIAA, NEN produce several other factors that could act synergistically in producing the characteristic cardiac lesions.

CHD may become clinically evident 1-5 years after the onset of the carcinoid syndrome. Right-sided valve disease may be well tolerated for months. Up to $20 \%$ of patients with carcinoid syndrome will present with $\mathrm{CHD}$ at the time of diagnosis. Symptoms may include fatigue, exertional dyspnea, peripheral edema, ascites and hepatomegaly.

\section{Stephen A. Geller, M.D.}

Department of Pathology and Laboratory Medicine

David Geffen School of Medicine, UCLA

Los Angeles/CA - USA

geller16st@gmail.com

\section{Fernando P. F. de Campos, PhD}

Department of Internal Medicine

Hospital Universitário - USP

São Paulo/SP - Brazil

fpfcampos@gmail.com
Resting 12-lead electrocardiography may be normal in up to $50 \%$ of cases, and Chest radiography is of limited value in the diagnosis of $\mathrm{CHD}$. Echocardiographic examination is the key modality in the diagnostic evaluation of $\mathrm{CHD}$ and in the assessment of its severity. Characteristic features include thickening of valve leaflets/cusps that become retracted and immobile, resulting in a combination of regurgitation and stenosis. Thickening of the chordae and papillary muscles may also be present what result in greater degrees of valve dysfunction. In a Mayo Clinic report of 75 patients with $\mathrm{CHD}$, tricuspid valve involvement was most common and regurgitation was the principal form of cardiac dysfunction. Pulmonary valve was often both insufficient and stenotic.

\section{Keywords: Carcinoid Heart Disease;} Tricuspid Valve; Pulmonary Valve; Carcinoma, Neuroendocrine; Serotonin.

\section{BIBLIOGRAPHY}

Lundin L, Norheim I, Landelius J, Oberg K, Thedorsson-Norheim E. Carcinoid heart disease: relationship of circulating vasoactive substances to ultrasound-detectable cardiac abnormalities. Circulation. 1988;77:264-9. PMid:2448062. http://dx.doi. org/10.1161/01.CIR.77.2.264

Palaniswamy C, Frishman WH, Aronow WS. Carcinoid heart disease. Cardiol Rev. 2012;20:167-76. PMid:22314145. http:// dx.doi.org/10.1097/CRD.0b013e31824c866e

Robiolio PA, Rigolin VH, Wilson JS, et al. Carcinoid heart disease: Correlation of high serotonin levels with valvular abnormalities detected by cardiac catherization and echocardiography. Circulation. 1995:92:790-5. PMid:7641358. http://dx.doi. org/10.1161/01.CIR.92.4.790

Simula DV, Edwards WD, Tazelaar HD, Connolly HM, Schaff HV. Surgical pathology of carcinoid heart disease: a study of 139 valves from 75 patients spanning 20 years. Mayo Clin Proc. 2002;77:139-47. PMid:11838647. 